\title{
Sound and genre in film and television: An introduction
}

\section{Birger Langkjær and Nicolai Jørgensgaard Graakjær}

\author{
MedieKultur 2010, 48, 1-4
}

Published by SMID | Society of Media researchers In Denmark | www.smid.dk The online version of this text can be found open access at www.mediekultur.dk

Genres are of central importance to media studies. Genres guide the thinking and work of people and institutions that produce media content, they structure how specific media products actually look and sound, and they are vital to what media users expect from their media. Most often genres are analysed in terms of thematic content such as news, romance or history programmes, or in terms of certain narrative structures, discursive practices or interactive forms. In this issue of MedieKultur, we extend this classical approach to media studies into the domain of sound by investigating the communicative audio styles of genres. What do genres sound like, especially in the "old" media such as film and television? Is there a recurrent use of music and sound effects in different genres, or can we say that each genre has defining auditory moments or sound signatures? How does sound communicate in specific generic contexts? The articles in this issue do not simply treat sound as an interesting but esoteric research area. Rather, each article intends to demonstrate that sound is an integral aspect of how different media genres are structured and render themselves to their audiences.

This issue presents findings from studies of sound in fiction film, audiovisual commercials (including trailers), television programmes and documentary films. Sound is understood both in terms of music and in terms of sound effects. The audiovisual interactions in the media and the communicative potential between media and their audiences are theorised and analytically examined both in their general aspects (audiovisual interaction) and in the specific context of the genre that defines their communicative situation. This issue 
does not examine all genres, as this would not be a single issue but a life-time study. Rather, both sound and genre are examined in order to contribute to genre studies, by demonstrating that most media genres are truly audiovisual.

In his article "Making fictions sound real - On film sound, perceptual realism and genre", Birger Langkjær examines the role that sound plays in making fictions perceptually real to film audiences, whether these fictions are realist or non-realist in content and narrative form. He argues that some aspects of film sound practices and the kind of experiences they trigger are related to basic rules of human perception, whereas others are more properly explained in relation to how aesthetic devices, including sound, are used to characterise the fiction and thereby make it perceptually real to its audience. Finally, he proposes that not all genres can be defined by a simple taxonomy of sounds. Apart from an account of the kinds of sounds that typically appear in a specific genre, a genre analysis of sound may also benefit from a functionalist approach that focuses on how sounds can make both realist and non-realist aspects of genres sounds real to their audiences.

In "Sound effects as a genre-defining factor in submarine films", Linda Maria Koldau argues that submarine films can be regarded as a genre with a specific semantic and syntactical structure, which heavily depends on the acoustemological nature of submarine warfare. The sound design in submarine films therefore has decisive dramatic and emotive functions. The article presents the sound effects most specific to submarine films and discusses the creative potential they offer both as diegetic sounds bound to submarine existence and as emotive cues with an immediate effect on the audience.

Palle Schantz Lauridsen investigates how the ten Danish Dogma films might be considered genre films and analyses the use of sound and music in these films in his article "Genhør med dogme 95" ("Dogma 95 reheard"). The Vow of Chastity proposed by the Dogma directors specifies that sound and image must never be produced separately. Using examples from all of the ten films, Lauridsen demonstrates both how the artistic intention formulated in the set of rules was handled during production and how it influenced the finished films. Even though each individual dogma film was quite different from an audio point of view, they nevertheless shared some audio characteristics, such as the audio jump cut and the abolition of the traditional dichotomy between diegetic and non-diegetic music.

In "Attitudes towards documentary soundtracks - Between emotional immersion and critical reflection", Iben Have begins with the fact that musical experience is often thought of as related to an emotional and imaginative engagement of the listener. Contrary to this, discourses of journalistic documentaries primarily relate to inferential knowledge systems in which the uses of (emotional) background music as a communicative device become an object of epistemological critique. Primarily through an analysis of four focus group interviews, this article discusses attitudes towards musical soundtracks in documentaries, attitudes being negotiated between emotional immersion and critical reflection, with the concept of manipulation as an underlying theme. 
How does audiovisual meaning come into being? Anders Bonde demonstrates an analytic-hermeneutic approach regarding multimodal semiosis in audio-visual media products in "Multimodal emergens via musik - Eksemplificeret ved en reklamefilm og en dokumentarfilm" ("Emergent forms of meaning-making using music in multimodal compositions - Exemplified through a television commercial and a television documentary"). As a theoretical framework, he incorporates the concept of emergence. Although usually associated with philosophy, systems theory and the sciences, this concept can prove instructive when examining multimodal compositions. Taking as a point of departure the expressive and semantic potential of music as one component in a coherent multimodal whole, several profound contributions to the field of music's semiotic potential in multimedia are examined. The overall approach is finally illustrated by analysing a television commercial for "SkandiaBanken", named Killarna ("The Guys"), and two scenes from a Danish documentary, Fogh bag facaden ("Fogh behind the Façade"). All three audio-visual clips include the same musical composition ("Waltz No. 2" of Dmitri Shostakovich), but it takes different roles and positions against the other modalities/resources, and in different genres, consequently, different types of meaning emergence are shaped.

In "Tv-reklamens musik i et tekstanalytisk perspektiv" ("The music of television commercials from a text analytical perspective"), Nicolai Jørgensgaard Graakjær examines music in television commercials from a text analytical perspective. An analytical framework is presented involving three interrelated analytic levels: the text, the co-text and the con-text. The level of con-text is presented as a transtextual matter of the relationship between the music appearing in the television commercial and music from outside the commercial. The level of co-text is presented as an analytical issue regarding the relationship between the different textual elements of the television commercial - a primary level of audiovisual signification is identified. The level of text is presented as a matter of the specific structure of music in television commercials and a number of formats are described. Each of these levels is discussed and further developed into a number of analytical categories, and throughout, the analytical levels and categories are illustrated with references to recent television commercials broadcast in Denmark.

When it comes to experiencing traditional sound design in movies, the audience is often presented with hidden mediation and production processes, that is, a sound track for which the audience is not aware of the sound designer's mediation and manipulation. In sharp contrast to this, many movie trailers include sound elements for which traces of the mediation process are clearly recognised and connected to various visual elements like camera movements, cuts, dissolves and speed variations, such as slow motion. In "Lyden av mediering - En utforsking av nyere sjangertrekk innenfor filmtrailere" "The sound of mediation - Exploring new aspects of the movie trailer genre"), Svein Høier analyses this use of sound elements which draws attention to the process of production and mediation, also involving a typology of obviously mediated audio-visual interactions, as well as a discussion of how the various sound elements function. 
In "At sanse smagen af tv-medieret mad" ("To sense the taste of TV-mediated food"), Katharina Thordis Raagaard examines how it is possible for a food programme to provide a sensory experience of taste despite the fact that the two most important senses - the actual smell and taste - are absent when we watch television. The argumentation is based on the concept of synaesthesia, which considers the senses as co-dependent. It is argued that food programmes use synaesthetic strategies in order to mediate a specific and sensory experience of taste. Finally, two Danish produced food programmes, "Spise med Price" (2008-2009) and "Du er hvad du spiser"(2005-2007), are analysed in order to establish a profound understanding of the food programmes sensory dramaturgical tools.

Finally, this issue presents 11 reviews of media literature, many of them books written about sound and music in media.

Birger Langkjar

Associate Professor, Ph.D.

Department of Media, Cognition and Communication University of Copenhagen, Denmark bilang@hum.ku.dk

Nicolai Jørgensgaard Graakjer Associate Professor, Ph.D. Department of Communication and Psychology University of Aalborg, Denmark nicolaig@hum.aau.dk 